\title{
YIELD AND QUALITY OF GROUNDNUT (ARACHIS HYPOGAEA L.) UNDER DIFFERENT ORGANIC SOURCES OF NITROGEN
}

\section{MOINUDDIN $^{1} \&$ MOHD KALEEM $^{2}$}

${ }^{1}$ Research Scholar, Department of Agronomy, Allahabad School of Agriculture, SHIATS, Allahabad, India

${ }^{2}$ Former Dean, Allahabad School of Agriculture \& Head, Department of Agronomy, SHIATS, Allahabad, India

\begin{abstract}
A field experiment was conducted during the kharif season of 2009 and 2010 to study the Yield and quality of summer groundnut (Arachis hypogaea L.) under different organic sources of nitrogen. The results revealed that combinations of different organic sources of nitrogen were recorded significantly influenced on yield and quality parameters of groundnut. The residual effect of organic manure significantly increased yield and yield attributes viz. Shelling \%, pod yield, haulm yield, harvest index, oil content, oil yield, protein content and protein yield of groundnut. The maximum pod yield and haulm yield were found to be higher with application of $25 \%$ RDN through FYM $+25 \%$ RDN through vermicompost $+25 \%$ RDN through poultry manure $+25 \%$ RDN through neem cake and also increased oil and protein content and yield of groundnut.
\end{abstract}

KEYWORDS: Groundnut, Neem Cake, Vermicompost, FYM, Poultry Manure, Yield \& Quality

Received: Aug 08, 2017; Accepted: Aug 28, 2017; Published: Sep 25, 2017; Paper Id.: IJASROCT201736

\section{INTRODUCTION}

Groundnut (Arachis hypogaea L.) has the first place among all the oilseed crops in India accounting for more than 40 percent acreage and 60 percent production in the country. India ranks first in area of 8.4 million hectares contributing 8.4 million tones production of groundnut (Tank et al., 2006). Among the oilseed crops, groundnut has first groundnut oil is primarily used in the manufacture of vegetable oil.

The residual effect of different organic treatments may be ascribed to increased availability of nutrients due to mineralization of organic materials, release of $\mathrm{CO}_{2}$, increasing fertilizer use efficiency, accumulation of organic carbon and improvement of soil physical properties (Badole et al., 2004). Use of organic manures to meet the nutrient requirement of the crop would be inevitable practices in the years to come from sustainable agriculture since, organic manures generally improve the soil physical, chemical and biological properties along with conserving the moisture holding capacity of soil and thus resulting in enhanced crop productivity along with maintaining the quality of crop produce.

\section{MATERIALS AND METHOD}

The experiment was carried out during kharif season 2009-2010 at the Crop Research Farm, Department of Agronomy, Sam Higginbottom Institute of Agriculture, Technology \& Sciences, (Deemed-to-be-University), Allahabad, Uttar Pradesh, India. The soil was sandy loam having pH 7.76, organic carbon $0.57 \%$, the lowest in available nitrogen $(204.25 \mathrm{Kg} / \mathrm{ha})$, phosphorus $(25.1 \mathrm{Kg} / \mathrm{ha})$ and medium in available potassium $(314.5 \mathrm{Kg} / \mathrm{ha})$. The experiment was laid out in Randomized Block Design, replicated thrice with 12 treatment combinations viz. 
$\mathrm{T}_{0}$, Control (R.D. of N.P.K. through fertilizer); $\mathrm{T}_{1},\left(100 \% \mathrm{RDN}\right.$ through FYM); $\mathrm{T}_{2},(100 \%$ RDN through vermicompost); $\mathrm{T}_{3},\left(100 \%\right.$ RDN through poultry manure); $\mathrm{T}_{4},\left(100 \% \mathrm{RDN}\right.$ through neem cake); $\mathrm{T}_{5},(50 \% \mathrm{RDN}$ through FYM $+50 \%$ RDN through vermicompost); $\mathrm{T}_{6},\left(50 \% \mathrm{RDN}\right.$ through FYM + $50 \%$ RDN through poultry manure); $\mathrm{T}_{7},(50 \% \mathrm{RDN}$ through FYM + $50 \%$ RDN through neem cake); $\mathrm{T}_{8}$, (50\% RDN through vermicompost + $50 \%$ RDN through poultry manure); $\mathrm{T}_{9},\left(50 \% \mathrm{RDN}\right.$ through vermicompost $+50 \% \mathrm{RDN}$ through neem cake); $\mathrm{T}_{10},(50 \%$ RDN through poultry manure $+50 \%$ RDN through neem cake) $; \mathrm{T}_{11},(25 \% \mathrm{RDN}$ through FYM $+25 \%$ RDN through vermicompost $+25 \%$ RDN through poultry manure $+25 \%$ RDN through neem cake). Control $=$ Recommended dose of fertilizer $\mathrm{N}_{30} \mathrm{P}_{60} \mathrm{~K}_{40}$ $\mathrm{kg} / \mathrm{ha}, \mathrm{RDN}=$ Recommended dose of nitrogen and P \& K inorganic fertilizer basal dose in all treatments. Groundnut cultivar Kaushal (G-201) was sown on 17 July 2009 and 27 July 2010, respectively, with the spacing of $30 \mathrm{~cm}$ x $15 \mathrm{~cm}$. All the recommended agronomic practices were followed to raise the crop. Various growth attributes were recorded at different stages of growth, while yield attributes and yield were recorded at harvest.

\section{RESULTS AND DISCUSSIONS}

\section{Effect of Organic Manure}

Based on the results of pooled data analysis are given in Table 1. The different organic manures used in this study had a significantly influenced on yield attributing characters and quality parameters of groundnut viz., Shelling \%, pod yield, haulm yield, harvest index, oil content, oil yield, protein content and protein yield of groundnut.

The increment of shelling percentage (19.59\%) and maximum shelling percentage (73.48\%) were recorded with the combination of different organic manures $(25 \%$ RDN through FYM $+25 \%$ RDN through vermicompost $+25 \%$ RDN through poultry manure $+25 \%$ RDN through neem cake) which was significantly higher (Table 1) as compared to other treatments. Shelling percentage too exhibited similar trend as the different organic treatments helped to increase the pod filling and test weight, which in turn favored the improvement in shelling percentage. Similar results have been reported by Abraham et al. (2008).

Application of $25 \%$ RDN through FYM + $25 \%$ RDN through vermicompost + $25 \%$ RDN through poultry manure $+25 \%$ RDN through neem cake also improved maximum pod yield (32.23 q/ha) and haulm yield (37.80 q/ha) than all the other treatment, respectively. The better response in yield attributes significantly maximum harvest index $(46 \%)$ and increment of harvest index (33.41\%) were recorded under the combination of different organic manures $(25 \%$ RDN through FYM $+25 \%$ RDN through vermicompost $+25 \%$ RDN through poultry manure $+25 \%$ RDN through neem cake).

The beneficial effect of organic manuring might be due to improvement in the physical condition of soil as well as increased availability of plant nutrients. This finding has been supported by Mishra (2001) and Rao and Shaktawat (2001). Combination of different organic sources of nitrogen has a significantly influenced on yield and quality parameters of groundnut. The increment of oil content $(28.82 \%)$ and protein content $(44.87 \%)$ as their yield in groundnut with the application of $25 \%$ RDN through FYM + $25 \%$ RDN through vermicompost $+25 \%$ RDN through poultry manure $+25 \%$ RDN through neem cake was found significantly higher (Table 2) than all the other treatment and also recorded maximum oil content $(48.13 \%)$, oil yield $(12.20 \mathrm{q} / \mathrm{ha})$ protein content $(24.31 \%)$ and protein yield $(5 \mathrm{q} / \mathrm{ha})$. Similar results have been reported by Thimmegowda (1993). 
Table 1: Effect of Different Organic Sources of Nitrogen on Yield Attributes of Groundnut (Pooled Data of Two Years)

\begin{tabular}{|c|c|c|c|c|}
\hline \multirow{2}{*}{ Treatment Combination } & \multicolumn{2}{|c|}{ Shelling Pod yield } & \multicolumn{2}{|c|}{ Haulm yield Harvest index } \\
\hline & (\%) & $(\mathrm{g} / \mathrm{ha})$ & (q/ha) & $(\%)$ \\
\hline 1. Control (R.D. of N.P.K through fertilizer) & 70.08 & 20.53 & 30.65 & 40.14 \\
\hline $2.100 \%$ RDN through farm yard manure & 61.44 & 15.60 & 26.61 & 38.30 \\
\hline $3.100 \%$ RDN through vermicompost & 68.27 & 17.36 & 27.60 & 39.98 \\
\hline 4. $100 \% \mathrm{RDN}$ through poultry manure & 63.75 & 14.06 & 24.85 & 34.48 \\
\hline $5.100 \%$ RDN through neem cake & 70.65 & 19.15 & 28.85 & 39.80 \\
\hline 6. $50 \% \mathrm{RDN}$ through farm yard manure + $50 \% \mathrm{RDN}$ through vermicompost & 73.11 & 26.10 & 34.01 & 43.38 \\
\hline 7.50\% RDN through farm yard manure $+50 \% \mathrm{RDN}$ through poultry manure & 72.23 & 19.93 & 34.53 & 36.69 \\
\hline 8. $50 \%$ RDN through farm yard manure $+50 \%$ RDN through neem cake & 73.34 & 27.20 & 33.60 & 43.49 \\
\hline 9.50\% RDN through vermicompost $+50 \%$ RDN through poultry manure & 72.46 & 23.78 & 32.38 & 42.32 \\
\hline $10.50 \%$ RDN through vermicompost $+50 \%$ RDN through neem cake & 72.02 & 28.83 & 37.53 & 43.44 \\
\hline 11. $50 \%$ RDN through poultry manure $+50 \%$ RDN through neem cake & 72.31 & 24.85 & 32.91 & 42.92 \\
\hline $\begin{array}{l}12.25 \% \mathrm{RDN} \text { through farm yard manure }+25 \% \mathrm{RDN} \text { through vermicompost }+ \\
25 \% \mathrm{RDN} \text { through poultry manure }+25 \% \mathrm{RDN} \text { through neem cake }\end{array}$ & 73.48 & 32.23 & 37.80 & 46.00 \\
\hline S. Em. $( \pm)$ & 0.69 & 1.49 & 1.61 & 2.05 \\
\hline $\mathrm{CD}(\mathrm{P}=0.05)$ & 1.38 & 3.09 & 3.35 & 4.25 \\
\hline
\end{tabular}

Table 2: Effect of Different Organic Sources of Nitrogen on Quality Parameters of Groundnut (Pooled Data of Two Years)

\begin{tabular}{|c|c|c|c|c|}
\hline \multirow{3}{*}{ Treatment Combination } & \multirow{2}{*}{\multicolumn{2}{|c|}{ Oil }} & \multirow{2}{*}{\multicolumn{2}{|c|}{ Protein }} \\
\hline & & & & \\
\hline & $\begin{array}{c}\text { Content } \\
(\%)\end{array}$ & $\begin{array}{l}\text { Yield } \\
(\mathrm{q} / \mathrm{ha})\end{array}$ & $\begin{array}{c}\text { Content } \\
(\%)\end{array}$ & $\begin{array}{l}\text { Yield } \\
(\mathrm{q} / \mathrm{ha})\end{array}$ \\
\hline 1.Control (R.D. of N.P.K through fertilizer) & 45.21 & 6.55 & 16.78 & 2.40 \\
\hline $2.100 \%$ RDN through farm yard manure & 37.50 & 3.47 & 20.01 & 1.86 \\
\hline $3100 \%$ RDN through vermicompost & 39.28 & 4.55 & 17.33 & 2.12 \\
\hline $4.100 \%$ RDN through poultry manure & 37.36 & 3.32 & 17.28 & 1.53 \\
\hline $5.100 \%$ RDN through neem cake & 43.75 & 5.84 & 19.56 & 2.61 \\
\hline $\begin{array}{l}6.50 \% \mathrm{RDN} \text { through farm yard manure }+50 \% \mathrm{RDN} \text { through } \\
\text { vermicompost }\end{array}$ & 45.61 & 8.93 & 20.23 & 3.85 \\
\hline $\begin{array}{l}7.50 \% \mathrm{RDN} \text { through farm yard manure }+50 \% \mathrm{RDN} \text { through poultry } \\
\text { manure }\end{array}$ & 34.60 & 5.28 & 22.21 & 3.17 \\
\hline $\begin{array}{l}8.50 \% \text { RDN through farm yard manure }+50 \% \text { RDN through neem } \\
\text { cake }\end{array}$ & 46.81 & 9.39 & 22.85 & 4.55 \\
\hline $\begin{array}{l}9.50 \% \mathrm{RDN} \text { through vermicompost }+50 \% \mathrm{RDN} \text { through poultry } \\
\text { manure }\end{array}$ & 45.23 & 7.90 & 20.78 & 3.62 \\
\hline $1050 \%$ RDN through vermicompost $+50 \%$ RDN through neem cake & 47.20 & 9.79 & 23.65 & 4.91 \\
\hline $\begin{array}{l}11.50 \% \text { RDN through poultry manure }+50 \% \text { RDN through neem } \\
\text { cake }\end{array}$ & 45.91 & 8.39 & 22.05 & 3.98 \\
\hline $\begin{array}{l}12.25 \% \mathrm{RDN} \text { through farm yard manure }+25 \% \mathrm{RDN} \text { through } \\
\text { vermicompost }+25 \% \mathrm{RDN} \text { through poultry manure }+25 \% \mathrm{RDN} \\
\text { through neem cake }\end{array}$ & 48.13 & 11.20 & 24.31 & 5.66 \\
\hline S.Em. $( \pm)$ & 0.91 & 0.20 & 0.65 & 0.13 \\
\hline $\mathrm{CD}(\mathrm{P}=0.05)$ & 1.89 & 0.43 & 1.36 & 0.28 \\
\hline
\end{tabular}




\section{CONCLUSIONS}

On the Basis of the findings of this experiment, it may be concluded with the combination of $25 \%$ RDN through $\mathrm{FYM}+25 \% \mathrm{RDN}$ through vermicompost $+25 \% \mathrm{RDN}$ through poultry manure $+25 \%$ RDN through neem cake, have a significant direct and residual effect of groundnut production. Application of different organic sources of nitrogen may be adopted for obtaining increased the yield and quality of groundnut. However, the results being based on two-year experimentation need confirmation by further trials.

\section{REFERENCES}

1. Abraham, T., Thenua, O.V.S., Singh, S.P. and Jacob, P. 2008. Performance of groundnut as influenced by organic and inorganic sources of nutrients and their method of application. Legume Res. 31 (3): 224-226.

2. Badole,S.B., More, S.N., Adsul, P.B., Shaikh, A.K. and Dhamak, A.L. 2004. Residual effect organic manures and inorganic fertilizers on yield and gross monetary returns of groundnut. J. Soil and Crops 14 (1): 196-197.

3. Mishra, C.M. 2001. Effect of farmyard manure and chemical fertilizers on the yield and economics of groundnut (Arachis hypogea L.) under rainfed condition. Madras Agricultural Journal 87 (7-9): 517-518.

4. Rao, S.S. and Shaktawat, M.S. 2001. Effect of organic manures, phosphorus and gypsum on growth, yield and quality of groundnut (Arachis hypoaea L.). Indian J. plant physiol. 6 (3): 306-311.

5. Vinutha. D. N, Aruna. Y. R, Jagadeesh. B. N\& Savitramma D. L, Genetic Correlation and Path-coefficient Analysis of Yield and its Components in Groundnut (Arachis hypogaea L.) Genotypes, International Journal of Agricultural Science and Research (IJASR), Volume 5, Issue 5, September - October 2015, pp. 89-94

6. Tank, D. A., Meisheri, T.G. and Usadadia, V.P. 2006. Integrated nutrient management in summer groundnut. Crop Res. $31(1)$ : 61-62.

7. Thimmegowada, S. 1993. Effect of residual fertility and direct fertilization on kernel, protein and oil yield of peanut grown in rice fallow. J. Sci. Food agric. 61: 385-387. 